The Common Agricultural Policy of the European Union the present and the future

Non-EU Member States point of view 



\section{INSTITUTE OF AGRICULTURAL AND FOOD ECONOMICS NATIONAL RESEARCH INSTITUTE}

\section{The Common Agricultural Policy of the European Union - the present and the future}

\section{Non-EU Member States point of view}

Editors:

dr Marek Wigier

prof. dr hab. Andrzej Kowalski

Proceedings of the International Scientific Conference

"The Common Agricultural Policy of the European Union - the present and the future" Multi-Annual Programme 2015-2019

"The Polish and the EU agricultures 2020+. Challenges, chances, threats, proposals" 5-7 December 2017 Stare Jabłonki, Poland

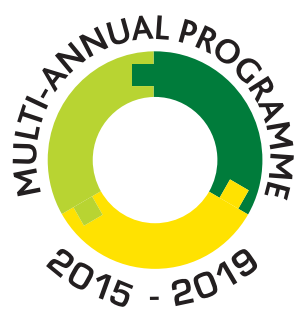

THE POLISH AND THE EU AGRICULTURES 2020+ CHALLENGES, CHANCES, THREATS, PROPOSALS

Warsaw 2018 
This monograph was prepared under the Multi-Annual Programme 2015-2019

"The Polish and the EU agricultures 2020+. Challenges, chances, threats, proposals".

The publication is a collection of selected papers delivered at the 22th edition of the International Scientific Conference organized by the Institute of Agricultural and Food Economics - National Research Institute. The theme of the conference was "The Common Agricultural Policy of the European Union the present and the future. The conference was placed on 5-7 December 2017 in Stary Jabłonki in Poland. Common Agricultural Policy was and still is one of the key pillars of European integration. Published in two volumes materials refer directly to the current and future of the CAP in EU and non EU member states, the strategic objectives and principles of agricultural policy for the agri-food sector and rural areas, address the issues of equilibrium between agriculture, forestry and land use, relate to the dilemmas for the EU budget and the CAP after 2020, CAP instruments and their adjustment, transformations of the rural economy and programming of the rural and agricultural policy, as well as productivity and production efficiency and tensions between sectoral action and between different models of territorial activities.

In the Scientific Committee of the Conference was participated: Prof. Andrzej Kowalski (IAFE-NRI, Poland), Prof. Drago Cvijanonivić (University of Kragujevac, Serbia), Prof. Thomas Doucha (IAEI, Czech Republic), Noureddin Driouech, PhD (CIHEAM, Italy), Prof. Szczepan Figiel (IAFE-NRI, Poland), Prof. Masahiko Gemma (Waseda University, Japan), Prof. Wojciech Józwiak (IAFE-NRI, Poland), Prof. Jacek Kulawik (IAFE-NRI, Poland), Prof. Yuriy Oleksiyovych Lupenko (IAE, Ukraina), Prof. Věra Majerová (CULS, Prague), Prof. Dimitre Nikolov (IAE, Bulgaria), Maire Nurmet, PhD (EMÜ, Estonia), Prof. Gabriel Popescu (ASE, Romania), Norbert Potori, PhD (AKI, Hungary), Prof. Włodzimierz Rembisz (IAFE-NRI, Poland), Piotr Szajner, PhD (IAFE-NRI, Poland), Prof. Alina Sikorska (IAFE-NRI, Poland), Prof. Jonel Subić (IAE, Serbia), Prof. Samuele Trestini (UNIPD, Italy), Prof. Olga Varchenko (Bila Tserkva National Agrarian University, Ukraine), Dipl.-Ing. Klaus Wagner (AWI, Austria), Marek Wigier, PhD (IAFE-NRI, Poland), Prof. Józef St. Zegar (IAFE-NRI, Poland)

In the Organising Committee of the Conference was participated: Małgorzata Bułkowska (IAFE-NRI, Poland), Anna Hankiewicz (IAFE-NRI, Poland), Joanna Jaroszewska (IAFE-NRI, Poland), Joanna Korczak (IAFE-NRI, Poland), Krzysztof Kossakowski (IAFE-NRI, Poland), Irena Mikiewicz (IAFE-NRI, Poland), Małgorzata Mikołajczyk (IAFE-NRI, Poland), Lech Parzuchowski (IAFE-NRI, Poland), Ewa Sierakowska (IAFE-NRI, Poland), Paulina Smakosz (IAFE-NRI, Poland), Leszek Ślipski (IAFE-NRI, Poland), Marek Wigier, PhD (IAFE-NRI, Poland).

Reviewers:

Professor Dimitre Nikolov, Institute of Agricultural Economics, Sofia, Bulgaria

Professor Gabriel Popescu, The Bucharest University of Economic Studies, Bucharest, Romania

Professor Samuele Trestini, University of Padva, Italy

Proofreader

Joanna Gozdera

Technical editors:

Joanna Jaroszewska, Barbara Pawtowska, Ewa Sierakowska, Kamila Tomaszewska,

Barbara Walkiewicz

Translated by

Summa Linguae S.A.

Cover Project

Leszek Ślipski

ISBN 978-83-7658-744-8

DOI: $10.30858 / \mathrm{pw} / 9788376587448$

Instytut Ekonomiki Rolnictwa i Gospodarki Żywnościowej

- Państwowy Instytut Badawczy

ul. Świętokrzyska 20, 00-002 Warszawa

tel.: (22) 5054444

faks: (22) 5054636

e-mail:dw@ierigz.waw.pl

http://www.ierigz.waw.pl 


\section{Contents}

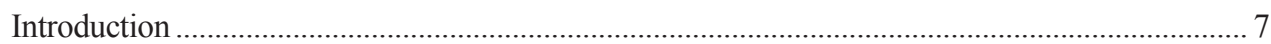

1 Urban agriculture: a framework for agricultural policy - present and future ......................... 15

Prof. Drago Cvijanović, Prof. Otilija Sedlak, Ph.D. Željko Vojinović

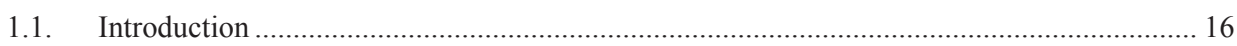

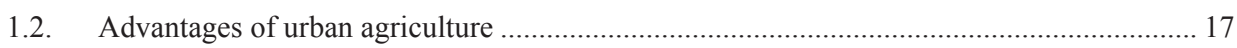

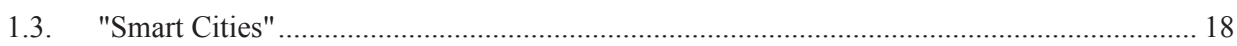

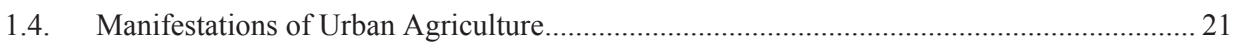

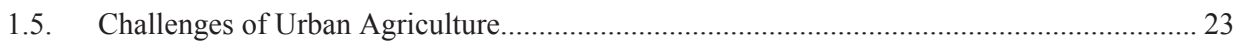

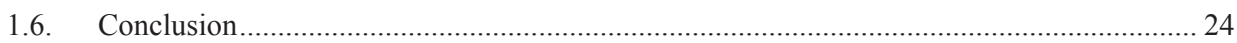

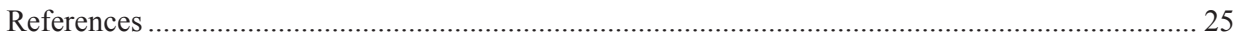

2 Land market and a village-keeping model of the agrarian system of Ukraine....................... 27

Dr Iurii Lupenko, Dr Valerii Zhuk

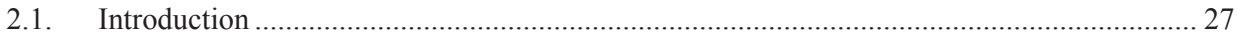

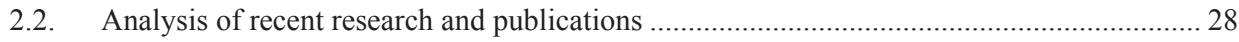

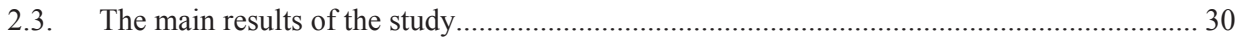

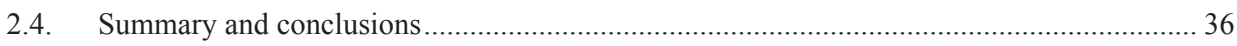

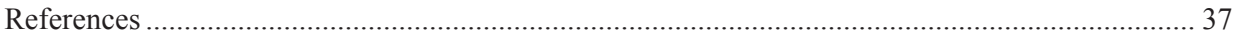

3 Agrarian policy in the European Union and financial support to Serbia................................ 38

PhD Biljana Grujić, PhD Predrag Vulović

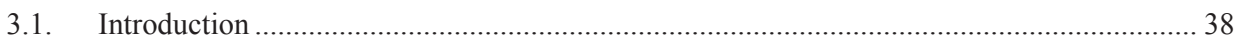

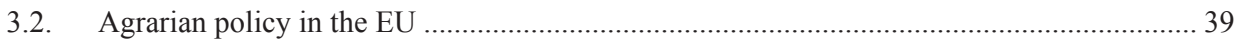

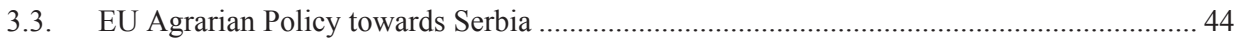

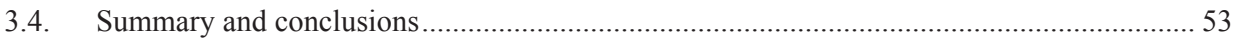

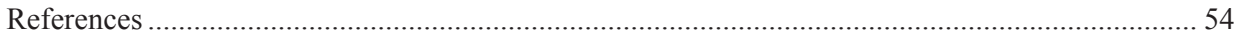

4 Ukrainian agricultural market regulation tools: their effectiveness and directions

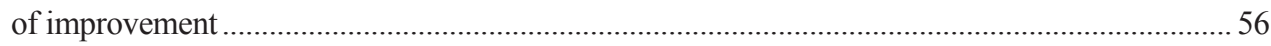

Prof. Olga Varchenko

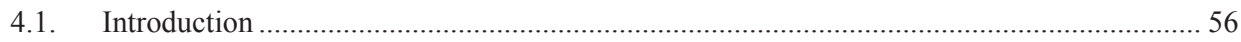

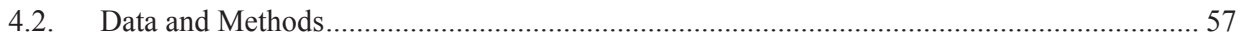

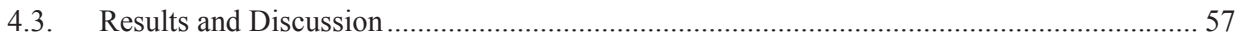

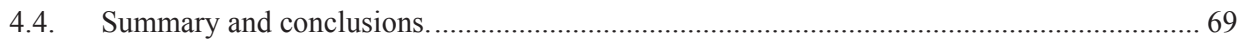

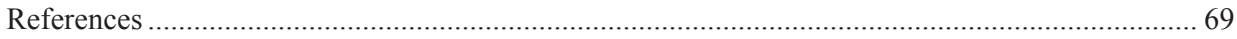


5 The Common Agricultural Policy of the European Union and the ways of its implementation in Ukraine

Dr Vasyl D. Zalizko, Prof. Nataliia M. Vdovenko, PhD Violeta L. Heraimovych, Assoc. Prof.

5.1. Introduction .71

5.2. The evolution of the EU Common agricultural policy .72

5.3. New priorities of the European Union for 2014-2020: strategic directions for Ukraine's agricultural sphere development

5.4. Organic component of the agricultural policy of Ukraine and common agricultural policy of the EU

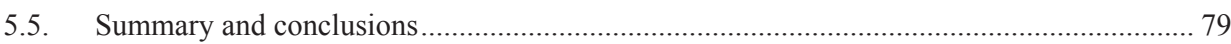

References 80

6 Farm's financing patterns and financial system development: evidence from Ukraine and Poland

Prof. Olena Oliynyk-Dunn, Prof. Viktor Adamenko

6.1. Introduction 81

6.2. Research methods 83

6.3. Results 84

6.4. Summary and conclusions 95

References .96

7 The moratorium on agricultural land sale as a limiting factor for rural development 97

Prof. Anatoliy Danylenko, PhD Tetyana Sokolska, PhD Olena Shust

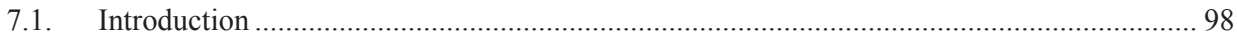

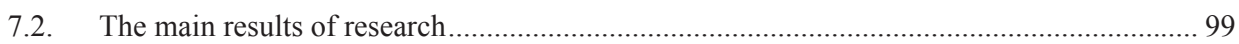

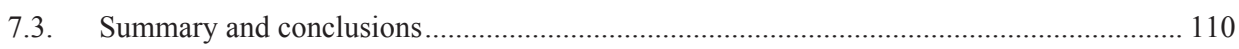

References

8 Solutions to the problems of rural territories development as a sign of their positive brand 114 Prof. Oleksandr Pavlov, Iryna Pavlova

8.1. Introduction 114

8.2. Problems of rural territories development 117

8.3. Branding as a marketing tool for solving the problems of rural territories development.... 124

8.4. Brand of rural territories development in Ukraine 127

8.5. Summary and conclusions 131

References 132

Instead of a summary 133

Annex I 


\title{
7 The moratorium on agricultural land sale as a limiting factor for rural development
}

\author{
Prof. Anatoliy Danylenko, academician of NAAS, PhD Tetyana Sokolska, \\ PhD Olena Shust,
} Bila Tserkva National Agrarian University, Bila Tserkva, Ukraine

DOI: $10.30858 / \mathrm{pw} / 9788376587448.7$

\begin{abstract}
The current state, conditions and possibilities on introduction the free circulation of agricultural land in Ukraine are investigated in the research, the main problems of its development are highlighted and the experience of agricultural land sale and lease of in European countries is analyzed.

The survey presents the results of interviewing shareholders and agricultural producers in two districts - Bila Tserkva, Kyiv region and Uman, Cherkassy region. The model of the agricultural land market should meet not only economic efficiency and expediency, but also contribute to the sustainable development of rural areas, where the circulation of agricultural land should be preceded by the introduction of appropriate restrictions. In order to prevent landlessness of peasants and the formation of latifundists, the free circulation of land can be implemented in two stages.

Stage 1: land inventory, cadaster and land management system, which includes four subsystems: 1) land rights (distribution and provision of land rights, legal registration of land borders, transfer of ownership rights or use rights through the conclusion of sales agreements or lease; the establishment of borders of land and property rights to them; the consideration and resolution of disputes concerning the rights on land plots and their boundaries.

Monetary valuation of land (valuation of land and property associated with it, provision of income on tax payments); 3) land use (land use control through territorial planning schemes and rules for land use at the national, regional and local levels; ensuring compliance with land use plans and rules; disputes over land use; compliance with resource-saving business practices and environmental measures); 4) infrastructure development.

Stage 2: opening the market for state and communal property land. The priorities on purchase are to be provided for the local communities, restriction on access the market for the legal entities, foreigners, introduction of other restrictions on the sale of agricultural land, the application the taxes differentiations on land sales, fees, etc.
\end{abstract}

Keywords: land, land relations, chornozem (black soil), sustainable development, agrisphere

JEL: Q15 


\subsection{Introduction}

Modern development and efficiency of agricultural production in Ukraine depends largely on the efficiency of the resource markets functioning with land being the main one. Today Ukraine is considered to be a country with significant agrarian potential due to its biggest areas of the black soil in the world. However, due to the moratorium on the free land market, agrarian sector of Ukraine is far behind the leading countries in terms of labor productivity, crop yields, animal productivity and other indicators. The structural imbalance caused by inefficient production structure resulted in distortions in agriculture, in particular, growing simple production cycle crops like cereals, sunflower and forage crops as well as anthropogenic pressure on the environment and excessive exhaustion of natural potential. Also, there is inefficient organization of rural areas, their depression, insufficient diversification of activities, unemployment and poverty of the rural population and even the vanishing of some villages from the map of Ukraine.

following:

Main limitation factors constraining the agricultural development are the

- $\quad$ high production costs;

- $\quad$ low financing level; high credit rates;

- lack of investments;

- $\quad$ price disparity;

- $\quad$ resource and structural imbalance of agricultural production;

- $\quad$ low level of technology and efficiency;

- devaluation of the national currency;

- $\quad$ high level of industrial risks, etc.

- $\quad$ legislative imperfection of normative-legal provision;

- $\quad$ absent legal protection of native producers;

- $\quad$ shadowing of native markets;

- $\quad$ not developed agricultural infrastructure;

- $\quad$ low wages and welfare of the rural population;

- deficit of professionals in agriculture.

One of the main deterrents is the moratorium on the land sales. Of more than $42 \mathrm{mln}$ ha or $70 \%$ of agricultural land of the Ukraine over $41 \mathrm{mln}$ ha or $97 \%$ is under moratorium. $68 \%$ of the moratorium land make private ownership land share of $6,9 \mathrm{mln}$ Ukrainian people. Two directions have been formed due to divergence of opinions and public interests of the authorities, businesses, scientists and shareholders today in the state - one stands for the moratorium, another - for a free land market. 
The extension of the moratorium is supported by the representatives of large businesses, which, under the veiled protection of peasant's interests and the preservation of national wealth, use shadow schemes for the alienation of agricultural lands.

That is, in fact, the shadow market of land related to the land plots sale already exists today. In the face of growing demand for agricultural products in the world, of significant reduction of natural resources, the existing format of land relations destructively affects socio-economic processes in rural areas and constrains the economic growth of the agrarian sector.

\subsection{The main results of research}

The current model of land use in Ukraine was formed in the issue of sharing the land owned by collective agricultural farms. Consequently, the peasants, who became the owners of the shares, were deprived of the minimum necessary means for their productive use and farming.

Due to the shortage of an efficient system of preferential lending, support infrastructure and the possibility of harvesting modern agricultural machinery share owners are forced to give up independent land use and lease it on the basis of contracts concluded in the amount of 4.7 million with the total land area of 16.6 million hectares.

There are also about 56 thousand of state agricultural land lease contracts for a total area of about 2.5 million hectares, accounting for a quarter of the state land bank. The feature of the rental market is its local monopolies on a specific territory where the land is cultivated by several tenants, and their price offers are approximately the same.

According to the Law of Ukraine "On Amendments to Certain Legislative Acts of Ukraine on Business Conditions Facilitation (deregulation)" No. 191VIII, 2015, the land of private peasant farms was allowed to be leased to agrarian holdings for minimum of seven years, and crop rotation compliance was not compulsory (The Verkhovna Rada of Ukraine, 2015).

In the absence of the law on soil fertility protection, which defines effective mechanisms for the soil quality monitoring and the measures to maintain their fertility, there was a negative tendency of humus loss, which decreased on average by 0.22 percent over the past 20 years in Ukraine.

The violation of crop rotation can contribute to soil fertility decrease as well. In particular, sunflower covers an area of over 30 percent of the arable land in some areas. In most cases, a crop is sown in the same field in three years while the recommended rotation makes six to seven years. The violation of 
the requirements for crop rotation, in addition to weed level crops diseases raise results in soil depletion.

During the transfer of land plots to a long-term lease, any possibility to control abusive tenants is lost, which causes the loss of the value of national chernozems.

In the EU countries, the lease is also a common form of land tenure, which, for example, accounts for over $90 \%$ of the total amount in Slovakia and the Czech Republic. In France, Belgium, Germany and Estonia - over 60\%; Great Britain - over $40 \%$. The lowest proportion of leased land is in Ireland, Denmark, Finland and Austria - up to $30 \%$.

Moreover, in most EU countries, the share of leased agricultural land in the total area of agricultural land use is increasing (Mostov'yak, M.I., 2009).

At the same time, the income of the shareholder to date is $\$ 37$, and the farmer's income is $\$ 418$ while in the European countries agricultural land lease cost makes $200-450 \$ /$ ha (Table 1 ).

Table 1. Comparison of the average rent for 1 hectare of land shares (shares) and the average cost of 1 hectare of land in Ukraine and Europe, \$ / ha

\begin{tabular}{|l|l|l|}
\hline Value/price & Ukraine & Europe \\
\hline average assessment of land value & $1150 \$ / \mathrm{ha}$ & $8000-32000 \$ / \mathrm{ha}$ \\
\hline average rent payment: & $35-84 \$ / \mathrm{ha}$ & $200-450$ /ha \\
\hline
\end{tabular}

Source: Compiled by the authors and (Swinnen, J., Van Herck, K. and Vranken, L., 2016).

The current cost of land lease in Ukraine is lower than it could be under its free sale and availability of loan capital. At the same time, a significant share of the differential rent I and completely differential rent II is received not by the landowner, but by the lessee, which, therewith, is not always a direct land user.

An analysis of lease agreements content and their making practice has shown that $20 \%$ of contracts do not even specify the possibility of the rent indexation. According to expert estimations, local budgets lose more than UAH 1 billion annually due to the underpaid rent.

Shadow schemes for the land sale under the moratorium on agricultural land and making bonded lease agreements have become widespread in Ukraine due to the lack of the proper land owners rights protection and state control for the observance of legislation in the field of land use.

Large agribusiness in Ukraine, has been lobbying the extension of the moratorium on agricultural land sale by motivating the unwillingness of the owners to sell their land. Having summed up the scientific views of the leading 
domestic and foreign scientists on the effective mechanism of forming land relations as well as the experience of the leading countries of the world, surveyed share owners and agricultural producers in two districts - Bila Tserkva, Kyiv oblast, and Uman', Cherkasy oblast in 2017.

The amount of rural population in Bila Tserkva district is $71.92 \%$ of the total, with 99,520 hectares of agricultural land area and 160 enterprises engaged in agricultural production. In particular, 38 of the enterprises are business partnerships, 3 - agricultural industrial cooperatives, 94 - farms, 18 - private enterprises, 5 - public industries, 2 - other companies (Bila Tserkva District State Administration, 2017).

The amount of rural population in Uman district is $94,66 \%$ of the total population, the total area of agricultural land - 106.2 thousand hectares ("Uman district administration," n.d.). 119 enterprises engaged in agricultural production including 81 farms operate in the district (Uman district state administration, 2017). The survey results are shown in Fig. 1-8.

Among the surveyed owners of land shares, in particular, in the Uman region, in February 2017, 59.8\% were categorically against selling their land, while $40.2 \%$ would give their consent, provided they were fairly priced. In the Bila Tserkva district, the situation is different, $61.8 \%$ of the respondents are ready to sell at good price, and $38.2 \%$ are strongly against, Fig. 1 .

Figure 1. The results of a survey on land owners' willingness to sell their share

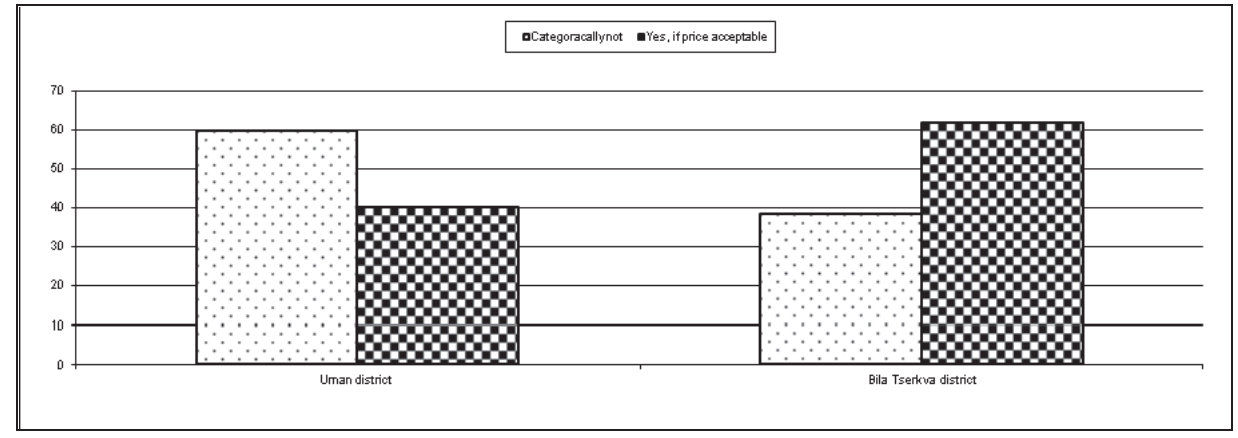

Source: Compiled by the authors.

As for the "fair price", the overwhelming number of owners of shares in both districts considers the maximum proposed in the questionnaire cost of over $\$ 10,000$, while the producers considered the one ranged $\$ 1000-3000$, explaining it with the lack of lending resources which makes it impossible to purchase necessary machines due to their high cost (Fig. 2). 
Figure 2. Results of the survey on a fair sale price of land a plot or share (1 ha) for commercial agricultural production under calling the moratorium

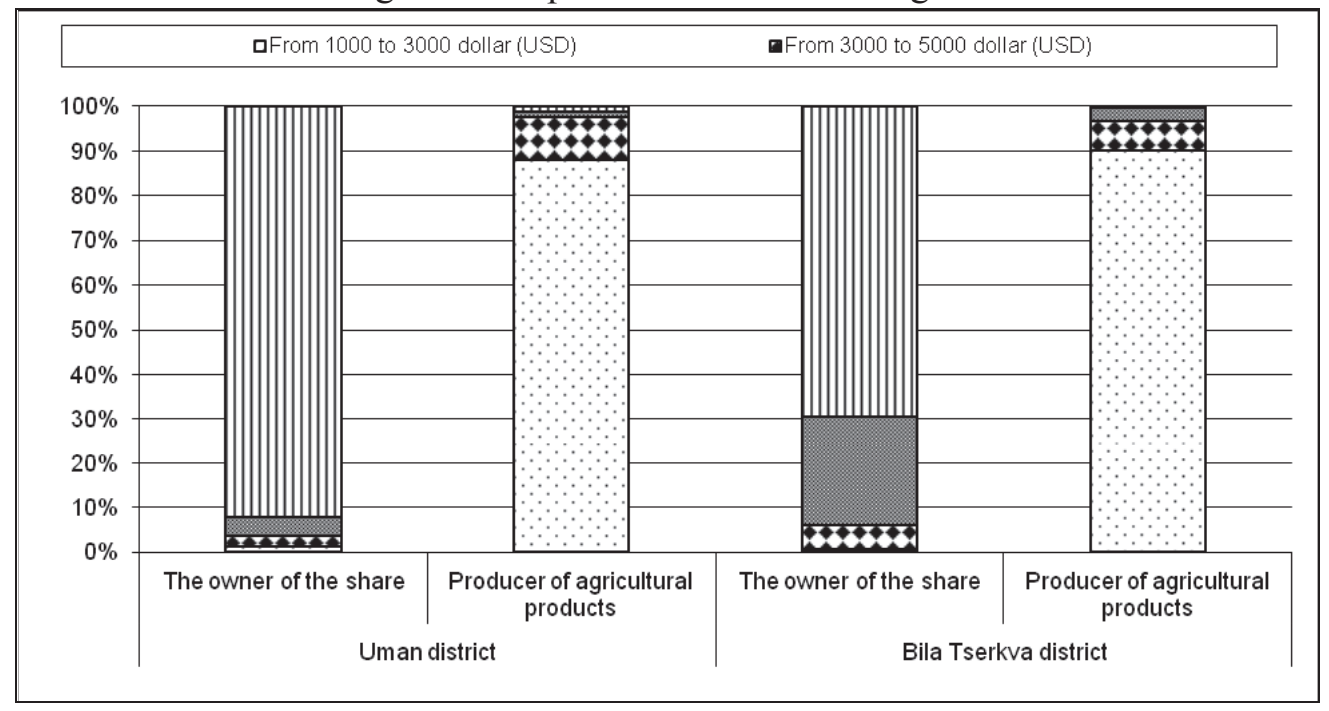

Source: Compiled by the authors.

As for the issues of calling the moratorium on agricultural land sale, the views of agricultural products manufacturers and land owners in both studied districts differ. Most manufacturers stand for the moratorium, due to unavailability of loans for land acquisition and the fear of "unfair" schemes by large holdings that would put medium and small farmers out of the market. The majority of large holdings are satisfied with cheap land lease as it enables them to make enormous profits while the owners do not mind calling the moratorium (55.1\% in the Uman district and $64.5 \%$ in the Bila Tserkva district) under compliance with appropriate socio-economic measures, including acquisition banning for foreigners, Fig. 3.

When asked what the land market should be on the condition of lifting the moratorium, the opinions of the districts producers differed. In particular, 50.1\% of the producers in the Uman district stood for a free market without restrictions vs. $23.1 \%$ in Bila Tserkva (Fig. 4), which can be explained by the significant share of foreign capital in the agricultural sector of Cherkassy region. 
Figure 3. Results of the survey on lifting the moratorium on land sales

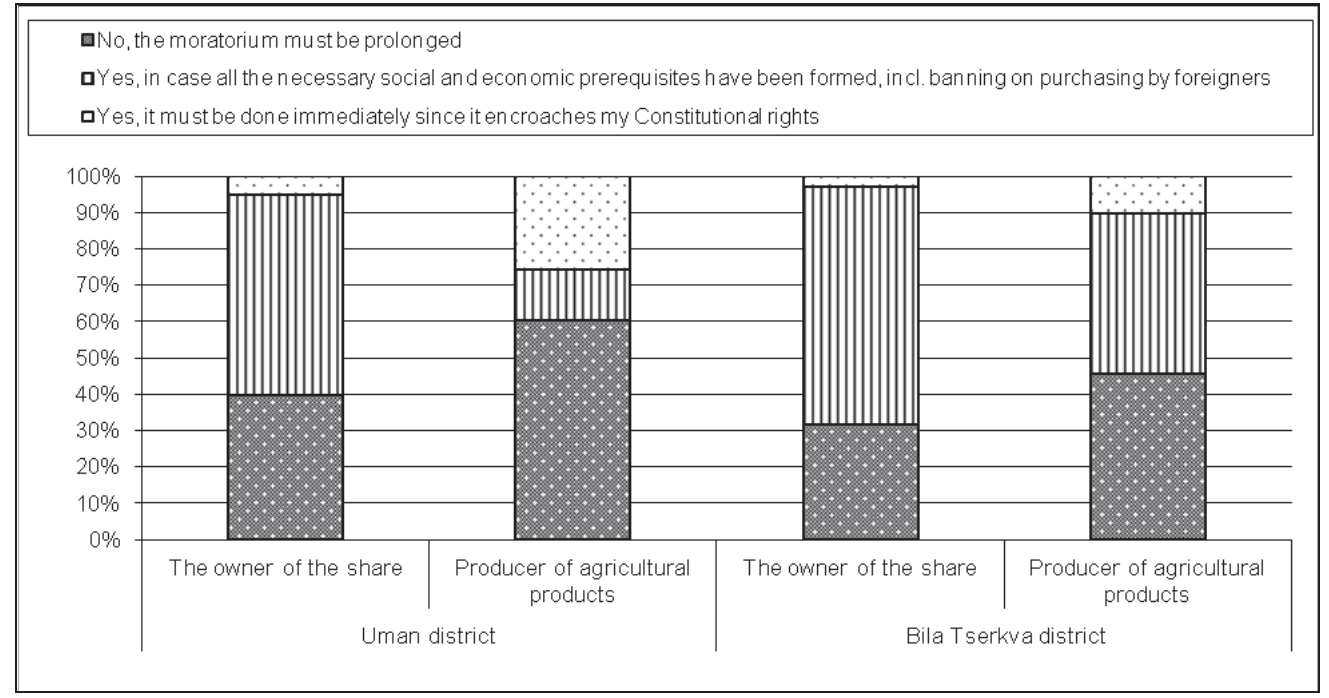

Source: Compiled by the authors.

Figure 4. Results of the survey considering the expected land market type in Ukraine

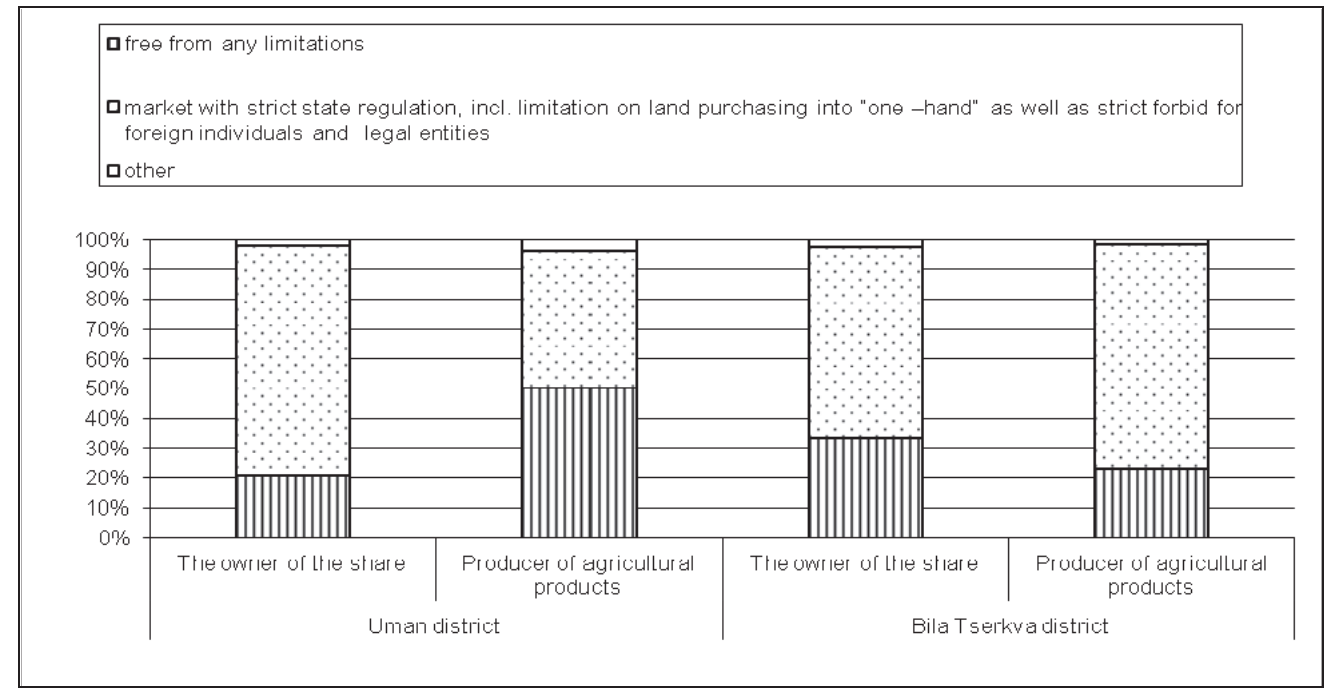

Source: Compiled by the authors.

We did not expect such a high share of land plots owners standing for the market with strict government regulation including restrictions in purchasing agricultural lands per customer and categorical banning on agricultural land purchasing by foreigners $(77.6 \%$ in the Uman district and $64.3 \%$ in the Bila 
Tserkva district). In our opinion, it was due to the severe economic situation in the country and the citizens' fear that it might deprive them of the land.

In general, the results of the survey revealed differences in the attitude of the land share owners and agricultural commodities producers to emphyteusis. The former were against it since they believed that there was a hidden danger of acquiring land ownership in which the perpetual leaser can use someone else's land without the owner's consent. $73.3 \%$ of land share owners in Uman and $59.4 \%$ in Bilal Tserkva district were against it (Figure 5).

Figure 5. Results of the survey on the respondents' attitude to emphyteusis

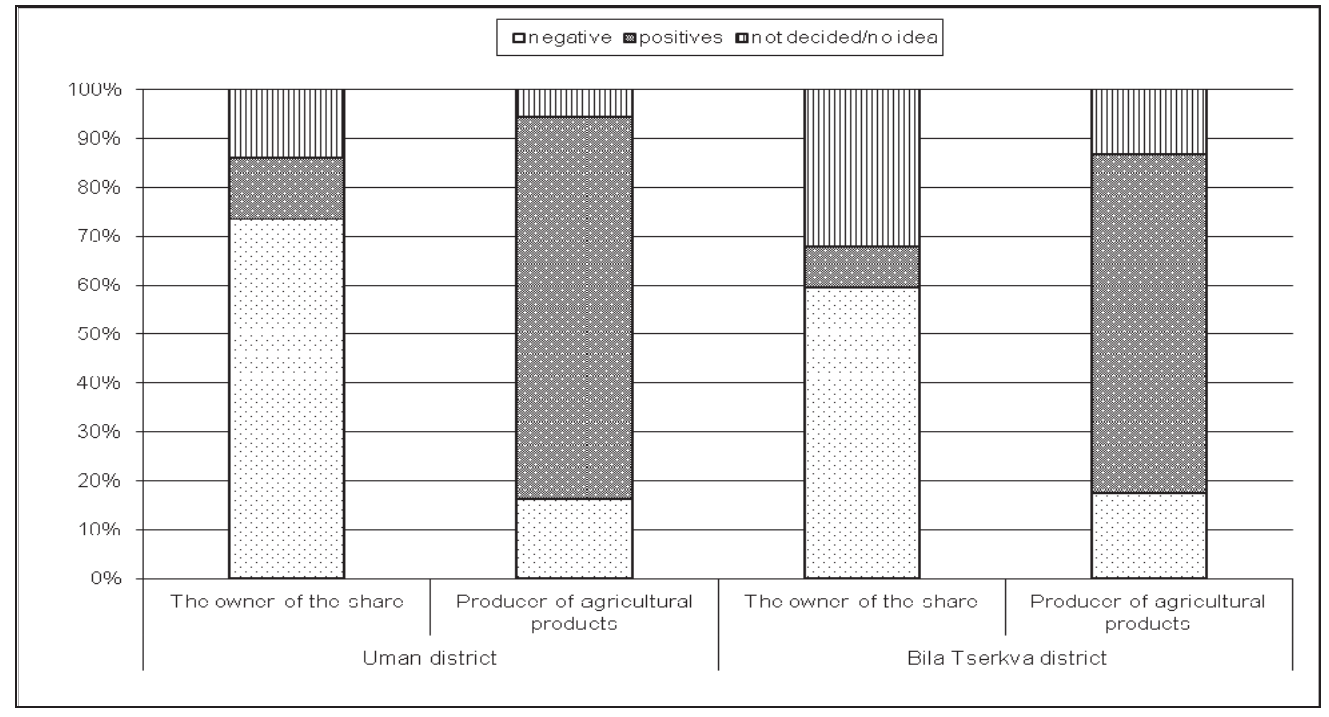

Source: Compiled by the authors.

However, $78.2 \%$ of producers in the Uman district and $69.3 \%$ in the Bila Tserkva district support the acquisition of long-term (up to 50 years) perpetual lease rights.

The survey results showed that the main concerns of shareholder owners were corrupt schemes of officials, pressure on land sales, low land prices. And in addition, political speculation in recent years has led to a negative attitude to the moratorium in the consciousness of Ukrainian citizens.

A number of significant changes took place in the political life of Ukraine towards decentralization of authority in 2017. In particular, in the regions studied, there was a unification of territorial communities, which still did not have the right to dispose of land outside their own settlements. At the same time, lease price for state land is sometimes less than the owner of a share when he leases his land to agricultural enterprises for rent, and a significant part of 
the land is not taken into account at all and forms the so-called "gray" market, and local budgets lose a significant portion of the funds. Thus, having no right to command their lands, communities lose their resources for development.

On December 7, 2017, the Verkhovna Rada renewed the moratorium on the sale of agricultural land until 2019. Such a situation greatly influenced the situation of agricultural producers. As a result, at the end of 2017, we conducted a second survey of respondents from the studied regions. The results differed significantly from the previous ones.

By that time the overwhelming majority of respondents voted for free circulation of agricultural land. In the Uman region, $75.9 \%$ of shareholders support the lifting of a moratorium on agricultural land in case all the necessary social and economic prerequisites have been formed, including banning on purchasing by foreigners and $18.4 \%$ expressed states that it must be done immediately since it encroaches citizens' Constitutional rights and only 5.7\% stood for the extension of the moratorium. As far as agricultural producers are concerned, $41.6 \%$ of the respondents stood for the moratorium extension, while $29.8 \%$ supported it in case all the necessary social and economic prerequisites have been formed, including banning on purchasing by foreigners and $28.6 \%$ for immediately since it encroaches my Constitutional rights. Completely different opinion of the agricultural producers was expressed in the Bila Tserkva district with only $23.7 \%$ of farmers standing against the abolition of the marathon, $61 \%$ supported it if all the necessary social and economic prerequisites have been formed, including banning on purchasing by foreigners has the same position and expressed $71.4 \%$ shareholders in the area (Fig. 6).

Interesting were the results of the survey on the question "who has the right to dispose of state-owned land", in both regions the majority are inclined to the fact that it is the combined territorial communities that can dispose of land, but a rather high percentage of respondents are afraid of corruption of local authorities, that is $12.4 \%$ Uman district and $24.2 \%$ in the Bila Tserkva district (Figure 7). 
Figure 6. Results of the survey on lifting the moratorium on land sales after the Verkhovna Rada extends the validity of the moratorium on sale or alienation of agricultural land for one year to 2019

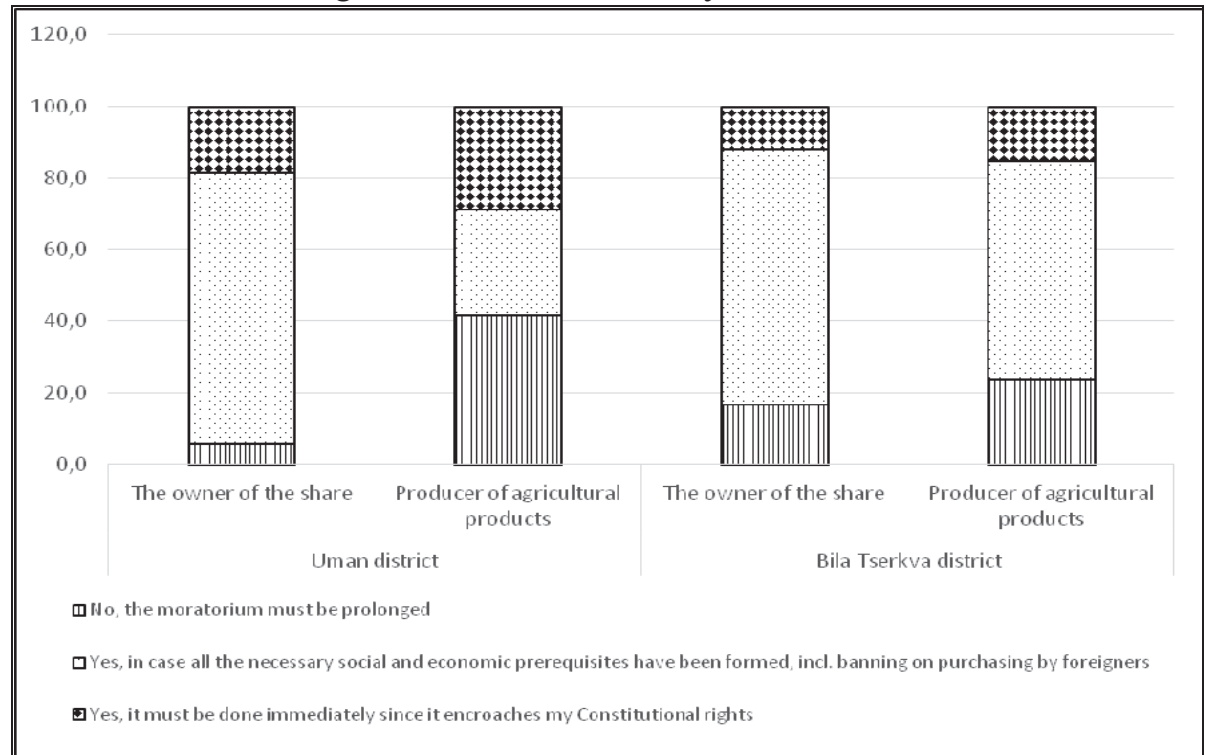

Source: Compiled by the authors.

Figure 7. Opinion on state land disposal by local community

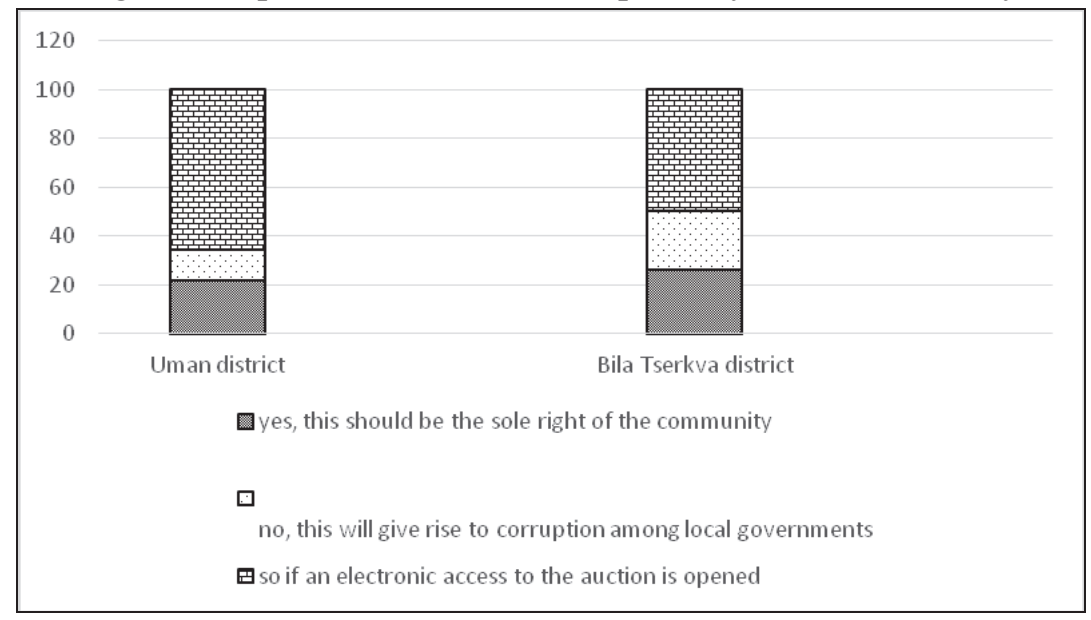

Source: Compiled by the authors.

Thus, currently, when the country's economy is in a fierce crisis, the delay in lifting the moratorium is one of the factors constraining the economic growth of the industry. 
Having analyzes the experience of the leading countries of the world, it can be affirmed that the land should be possessed by those who cultivate it.

The most common regulatory instruments and constraints applied in world practice are the following: restrictions on the subject structure of buyers; qualification requirements for buyers; establishment of a transitional period during which there are temporary restrictions on the purchase / sale of land for foreigners, legal entities, etc.; limited sizes of land plots (both maximum and minimum) that may be owned or used by a natural person and legal entities; minimum and maximum terms of land lease; prohibition or restriction on changing the purpose of the land; price regulation; introduction of progressive scales of taxation of land transactions; environmental restrictions on land use; the establishment of a pre-emption right for the purchase of agricultural land depending on the country: the tenant, the owner of the adjacent land, a specialized agency.

For example, in Germany, the Law on the agricultural land sale regulates the procedure for the land sale and for the sale of land of a predetermined size, which varies depending on the federation, and must be approved by the regulatory body (in Bavaria, the minimum size of the plot for which the approval from the regulating body is required makes 2 hectares, in Lower Saxony -1 hectare, and in Saxony -0.5 hectares). The regulator checks whether there are pre-emptive rights to this land and may prohibit the sales. For example, the ground for refusals may be ineffective distribution of agricultural land or speculative suspicions (the price is too high or too low).

In the Czech Republic the following persons have the predominant right to purchase the state land: farmers, landowners, partners in corporate farms, members of cooperatives and the relevant restitution persons. Preferential rights are often used when state land is privatized. About $90 \%$ of all state land that was privatized in 2006 was bought by people who use their prevailing rights (Ciaian Pavel, Kancs d'Artis, Swinnen Jo and al., 2012). The abovementioned list clearly shows that these were the units able to lease land from the state at the beginning of the reform period, i.e. former heads of state and collective farms were in a favorable situation.

In Hungary, land ownership rights are prohibited for legal entities (both domestic and foreign, as well as land ownership rights, local governments and public organizations). Exceptions to this rule are church organizations with legal personality who have acquired the right to ownership by virtue of a will or on the basis of a donation agreement. The mortgage lending company may also acquire ownership of arable land for a limited period of time. In addition, there is an upper limit (300 ha) which may be owned by a physical person. 
In Bulgaria, a law was passed to prevent the excessive fragmentation of agricultural land, which states that the site may not have a separate right of ownership if it is less than 0.3 hectares $(0.1$ ha for vineyards and 0.2 ha for pasture). In Turkey, the minimum size below which the agricultural area cannot be divided is 0.1 hectares (Ciaian Pavel, Kancs d'Artis, Swinnen Jo et al., 2012).

Romania is the only country in Europe that has not made any notification to the EU for the imposition of restrictions on the purchase of land by foreigners. In this area there are other several million hectares owned by foreign tenants with the right of first refusal to purchase. Interestingly, the Romanians do not have even a hectare of arable land in any EU country, according to the confederation of farmers. Accession Treaties concluded by the EU countries left to the discretion of each issue the sale of land to foreign countries, it is one that keeps the food safety of each state. In this context, the issue of land sales is a national, not a community (Butnaru, Elena-Sinziana, 2015).

Consequently, as the free land flow is one of the most important levers in the development of the agrarian sector, its use requires very accurate actions, a balance should be between economic benefits and the social effect must be found. For this, it is necessary to create the appropriate institutional and macroeconomic conditions and allow the land user, who cultivates the land, to feel like the owner of the land. At the same time, legal and social security and environmental safeguards should be legally enforceable, which would protect both the land owner and the agricultural producer. That is, the model of the agricultural land market should meet not only economic efficiency and expediency, but also contribute to the sustainable development of rural areas. First of all, the circulation of agricultural land should be preceded by a clear definition of the type of agrarian structure of Ukraine, taking into account the resource-saving economy and ecologically and socially oriented development.

It is worth mentioning that the domestic economists P. Gaiducky, Yu. Lupenko, A. Tretyak, P. Sabluk, A. Martin, M. Martynyuk and many others have made a significant contribution to solving this problem, In their view, the formation of an effective landowner and its involvement in economic circulation is one of the main conditions for the formation of an economic platform for agrarian reform. However, scientists are unanimous in the opinion that the procedures for opening a free market for land must precede the development of an economic mechanism and legislative framework for regulating this process (Gaiducky, P. I., 2004; Lupenko, Yu. O., Khodakivska, O. V., 2016; Tretyak, A.M., 2013; Sabluk P. T., 2006; Martin, A.G., 2011; Marty'nyuk, M. P., 2016).

Scientists prove that the extension of the moratorium on the purchase and sale of agricultural land restricts the rights of millions of owners who are not 
able to dispose of their land, makes it impossible to use innovative technologies because of irrational land holdings. In particular, the Institute of Agrarian Economics has developed the so-called land road map, according to which the introduction of a free land market becomes possible only after certain conditions are fulfilled. It means the development of a consolidated model for the further development of land relations; creation of the legislative base, market infrastructure, completion of inventory of land; solution of problems of the state land cadastre (filling the cadastral system, demarcation of adjacent territories, etc.); financial and credit support for the purchase of land by peasants.

Y. Lupenko believes that in the case of uncontrolled introduction of purchase and sale of agricultural land in circulation up to 105 billion UAH may appear, which may result in money depreciation and the development of inflationary processes (Lupenko, Yu. O., Khodakivska, O.V., 2016) since land fragmentation does not allow the land to be used effectively.

M. Martyniuk also proposes the gradual introduction of the land market, although it is obvious that in the first stage there will be a place of speculation on land shares; impairment of land (the experience of other countries has shown that after the opening of the market in the first two years the value falls, and then equals); the risk of buying land by several large players, but delaying the introduction of the land market will lead to a reduction in the capitalization of agribusiness, since land fragmentation does not allow for the efficient use of land (Marty'nyuk, M. P., 2016).

The draft law "On Amendments to Certain Legislative Acts on Improving the Legal Regulation of Land Use for Agricultural Use (emphyteusis)", developed by the Ministry of Agrarian Policy and Food of Ukraine, was widely publicized in the society and among scientists, but it was deeply criticized because it opens the space for land speculation giving the opportunity to rent land at a low price, and then sell the right to lease much more expensive. In fact, this is an attempt to introduce a turnaround of land by passing the moratorium.

According to D.V. Ivanovsky, on the one hand, it creates conditions for raider seizure of farmland, and on the other it allows to evade tax payments (Ivanovsky, D.V., 2016). Obviously, such an innovation threatens the peasants, since there are no clear rules on purchasing prices and indexation, and the retiree has no opportunity to sell his share, lives on a meager pension. In addition, under the agreement of emphyteusis, the user has the right, without the permission of the land owner, to sell his right to use the site to a third person. 


\subsection{Summary and conclusions}

Consequently, the issue of lifting the moratorium on land sales is extremely relevant for Ukraine, and therefore it requires detailed scientific substantiation of the ways of its solution. We propose to introduce the agricultural land market in two stages.

At the first stage, it is proposed to carry out a complete land inventory, cadastre and land management system, which includes four subsystems: 1) land rights (distribution and provision of land rights, legal clearance of land plots, transfer of ownership rights or use rights through the conclusion of sale or lease agreements, the establishment of boundaries of land and rights to them, the consideration and resolution of disputes regarding the rights to land parcels and their boundaries, and 2) monetary valuation of land (valuation of land and related land on, providing revenue through taxes); 3) land use (land use control through territorial planning schemes and rules for land use at the national, regional and local levels; ensuring compliance with land use plans and rules; disputes over land use; compliance with resource-saving business practices and environmental measures); 4) infrastructure development.

Extremely important for Ukraine is the establishment of safeguards for public land (trails, meadows, banks, airspace) and the right of territorial communities to buy disputed lands (unclaimed units, land of so-called dead heritage, socially unprotected, unallocated units, land owners, whose age is over 75-80 years old.

In order to prevent excessive concentration of agricultural land in the ownership of one owner, restrictions should be set i.e. no more than 300 ha in one hand. When purchasing agricultural land, the owner must have a guaranteed right to a loan for 10 years in the amount of $70 \%$ of the value of land (not more than 100 hectares of land purchased).

In order to prevent the encroachment on the territorial integrity of Ukraine and its food security, it should be forbidden to sell land to foreign citizens as peasants will not be able to compete with foreign capital.

At the second stage on opening the state land market and communal property the right to form the agricultural land market structure should belong solely to local communities. It should provide for restrictions on access to the market of legal entities, residents of other regions, foreigners, the introduction of other restrictions on the sale of agricultural land, the establishment of levels of taxes on land sales, fees, etc. The state and society must tightly control the transparency of the decision-making mechanism at the local level and adhere to the balance between social and economic benefits for individual rural areas. In 
order to prevent corruption, all land transactions should be made through a single electronic window.

The priority right to purchase is given to the members of rural communities living in this territory, citizens of Ukraine, small agricultural enterprises, farmers who have been engaged in agricultural activity for at least 5 years and have proved their professional ability (have a specialized education, use land rationally, investing the funds for increasing its potential). The ability to in-depth processing of agricultural products and the creation of the product for final consumption with high added value is extremely important. Also, the first right to purchase the land should be given to farmers engaged in animal husbandry and generated added value.

The law must necessarily provide for the social responsibility of owners of agricultural land. In particular, applicants must be registered in the territory where they buy land, and for at least 5 years work there. In the case of nonfulfilment of these conditions, the legally developed mechanisms of alienation of these lands in favour of the community should be activated.

At the second stage, the infrastructure of the land market, land exchanges, land banks and medium and long-term mortgage lending systems should be actively developed.

It is extremely important for Ukraine to adopt a law on land consolidation for agricultural producers holding more than 1,000 heads of cattle, with a precise outline of mechanisms that, after the launch of the land market, will not allow unbalanced work of agricultural holdings. After all, it was they who in the most difficult times for the peasants made it possible to preserve the social infrastructure in the countryside, to create jobs.

It is worth noting that a number of draft laws were introduced to the Verkhovna Rada, which in various editions proposed to resolve the issue of the introduction of the land market and the transfer of powers to dispose of lands OTG, but the moratorium continued. One of the conditions for granting Ukraine a loan tranche, the IMF proposes lifting the moratorium. Despite the fact that the proposed bills contain some discussion clauses, they would automatically remove the moratorium and would be a powerful impetus to the development of the Ukrainian agrarian sector.

The absence of free land market, the introduction of which has been put off for decades in Ukraine have resulted in inefficient use of land resources, structural imbalances in the agricultural sector, rural depression, unemployment and poverty in rural areas. 
Land must have an owner which can fulfill his constitutional right to dispose the land, take care of its quality and efficient production only under a free market.

However, free turnover of land can be implemented in two phases in order to prevent appearance of landless peasants and landowners. Free market must be preceded by developing legal preventive measures to protection of land areas (priority right to purchase, limits in the size of land area, providing medium and long-term mortgage for farmers, development of land market infrastructure, etc.).

\section{References}

1. Bilocerkivs 'ka rajonna derzhavna administraciya [Bila Tserkva District State Administration]. [Electronic resource]. Retrieved from: http://bcrda.kiev.ua.

2. Butnaru, Elena-Sinziana (2015). Lease and its impact on the land market. Scientific Papers Series Management, Economic Engineering in Agriculture and Rural Development, Vol. 15. http://managementjournal.usamv.ro/ pdf/vol.XV_1/Art10.pdf

3. Chikalo, I.(2013). Insty'tucijne zabezpechennya funkcionuvannya ry'nku zemli v Ukrayini [Institutional provision of functioning of the land market in Ukraine].Economist- No 3, pp. 29-31 [in Ukrainian].

4. Ciaian Pavel, Kancs d'Artis, Swinnen Jo and al., (2012). Sales market regulations for agricultural land in EU member states and candidate countries. Available at: http://aei.pitt.edu/58517/1/Factor_Markets_14.pdf.

5. Gaiducky, P. I. (2004). Moratory'j na prodazhu zemly' zatyagy`vaet agrarnuyu reformu [Moratorium on the sale of land drags agrarian reform]. Biznes - Business - No 7 (578), pp. 32-33 [in Ukrainian].

6. Herck, Kristine Van and Vranken, Liesbet (2013). Direct payments and land rents evidence from new member states, no. 62. Available at: http://ageconsearch.umn.edu/bitstream/157121/2/FM62\%20Direct\% 20Payments\%20and\%20Land\%20Rents.pdf.

7. Ivanovsky, D.V. (2016) Ry'nok zemel' v Ukrayini: problemy' zakonodavchogo regulyuvannya [Land market in Ukraine: problems of legislative regulation]. Rozbudova derzhavy' i prava: py'tannya teoriyi ta konsty 'tucijnoyi prakty'ky'- Building State and Law: Issues of Theory and Constitutional Practice No 6 (p2), pp. 3-8 [in Ukrainian].

8. Khodakovsky, E.I. (2001) Stabilizaciya ekonomichnoyi sy`tuaciyi v konteksti ry'nku zemli [Stabilization of the economic situation in the context of the land market] Kyiv : NNT IAE. - 335 p [in Ukrainian].

9. Lupenko, Yu. O., Khodakivska, O. V. (2016). Naukovi zasady zaprovadzhennya rynkovoho obihu zemel' sil's'kohospodars'koho pryznachennya [Scientific basis of introducing market circulation of agricultural land]. Ekonomika APK - The economy of AIC, No 12, pp. 5-15 [in Ukrainian]. 
10.Martin, A.G. (2011) Regulyuvannya ry`nku zemel` v Ukrayini: monografiya [Regulating the Land Market in Ukraine: : monograph] Kyiv : Agrar Media Group.- $254 \mathrm{p}$.

11.Marty’nyuk, M. P.(2016). Ekonomichni peredumovy` ta modeli zapusku ry'nku zemel' $\mathrm{v}$ Ukrayini [Economic preconditions and models for launching the land market in Ukraine]. Ekonomika APK - The economy of AIC, No 12, pp. 16-21 [in Ukrainian].

12.Mostov'yak, M.I.(2009) Dosvid krayin Central'noyi ta Sxidnoyi Yevropy'v uprovadzhenni ry'nku sil`- s'kogospodars 'ky'x zemel' [ Experience of Central and Eastern European Countries in the implementation of the agricultural land market]. Strategichni priory`tety`- Strategic priorities, No 1(10), pp. 159-166 [in Ukrainian].

13. Nizalov, D. Chmelova, K. Kubakh, S. al. (2016) Land Governance Monitoring in Ukraine 2014-2015/Capacity development for evidence-based land \& agricultural policy making. [Electronic resource]. Retrieved from: http://www.kse.org.ua/en/research-policy/land/governancemonitoring/yearbook-2014-2015.

14.Novakovsky, L Nacional'na dopovid' shodo zavershennya zemel'noyi reformy' [National report on the completion of land reform]. Kyiv : Agrar. Science.- 48 p.

15. Oglyad stanu zemel'ny'x vidnosy' $n \mathrm{v}$ Ukrayini [Review of the state of land relations in Ukraine]. [Electronic resource]. Retrieved from: http://land.gov.ua.

16. Sabluk P. T. (2006). Rozvytok zemelnykh vid nosyn v Ukraini [Development of land relations in Ukraine]. Kyiv : NNT IAE. -335 p. [in Ukrainian].

17.Swinnen, J., Van Herck, K. and Vranken, L.( 2016). The diversity of land markets and regulations in Europe, and (some of) Its causes. The Journal of Development Studies, no. 52 (2), pp.186-205.

18.Swinnen, J.,Vranken, L. (2009). Land \& EU accession review of the transitional restrictions by new member states on the acquisition of agricultural real estate. Available at: https://www.ceps.eu/publications/landeu-accession-review-transitional-restrictions-new-member-states-acquisition

19. The Verkhovna Rada of Ukraine (2015), The Law of Ukraine " On Amendments to Certain Legislative Acts of Ukraine on Facilitation of Business Conditions (deregulation)", Golos Ukrayiny`,vol. 73.

20.Tretyak, A.M. (2013). Zemleustrij in Ukraini theory, Methody [Land Management in Ukraine: Theory, Methodology]. Kyiv, Ukraine: Grin D.S., 648.

21.Umans'ka rajonna derzhavna administraciya [Uman district state administration]. [Electronic resource]. Retrieved from: http://bcrda.kiev.ua. http://umanrda.gov.ua.

22.Voronina, Yu. E. (2009) Udoskonalennya derzhavnogo regulyuvannya prodovol'choyi bezpeky'[ Improving state regulation of food security]. Teoriya ta prakty'ka derzhavnogo upravlinnya - Theory and practice of public administration- No 1, pp. 321-329 [in Ukrainian]. 